\title{
Japanese language and "Characters": From the Perspective of TEACHING JAPANESE AS A Foreign LANGUAge
}

\author{
SHUKURI Yukiko \\ Toyo International Culture Academy, Japan \\ shi9ri@hotmail.com
}

\begin{abstract}
This paper introduces current status of "role language" and the "speaker's character" and their applications in Japanese teaching materials. Besides it studies the knowledge of Russian learners of Japanese and carefully examines their knowledge of four typical kinds of "role language" in Japanese anime and manga by using a questionnaire and follow-up interviews. From the results of the textbook research, the following two things are revealed; (a) first person pronouns except for watashi are rarely used, (b) there is not enough explanations about different "speaker's characters" in detail. Furthermore, findings of the questionnaire show that some of the learners who have the same impression of the characters as Japanese native speakers, wrongly connect a certain "role language" to illustrations of a character, and results of as much as three kinds of "role language" have a low positive correlation with the learners' results of the Japanese Language Proficiency Test. Results also reveal that all four kinds of "role language" have no correlation with other factors, such as student's duration of learning Japanese, or frequency of the use of Japanese outside the classroom.
\end{abstract}

Keywords: Japanese learners; role language; speaker's character; first person pronouns; sentence ending expressions

\section{Povzetek}

Raziskava razsvetljuje trenutno stanje raziskav o "jeziku vlog" in "govorčevemu liku" ter njuni uporabi $v$ učnem materialu za učenje japonskega jezika. Poleg tega obravnava ruske učence japonskega jezika, in preko vprašalnika ter sledilnih intervjujev ocenjuje njihovo poznavanje štirih tipičnih "vlog jezika" $v$ japonskih animejih in mangah. Rezultati raziskave o učnem materialu podajajo dva zaključka; (a) osebni zaimki v prvi osebi, z izjemo watashi, so zelo redki, in (b) v splošnem ni dovolj razlag o različnih "likih, ki jih predstavljajo govorci". Obenem rezultati vprašalnika razkrijejo, da nekateri ruski učenci, ki izkazujejo enak vtis o likih kot njihovi japonski kolegi, napačno povezujejo jezik določene vloge z ustreznimi ilustracijami tistega lika. Tako imajo rezultati treh tipov "jezika vlog" statistično nizko pozitivno korelacijo z učenčevimi rezultati na preizkusu znanja japonskega jezika. Nenazadnje rezultati kažejo tudi na to, da prepoznavanje štirih tipov "jezika vlog" ni odvisno od trajanja učenja japonskega jezika niti ne od uporabe japonščine izven študijskega programa.

Ključne besede: učenci japonščine; jezik vlog; govorčev lik; osebni zaimki v prvi osebi; izrazi na koncu stavka 


\section{Introduction}

In Japanese, it is possible to make a variety of sentences expressing the same meaning by changing either the first person pronoun used in them or the expression at the end such sentences. For example, in Japanese anime and manga, a cat is said to speak in a "cat language," or and an old professor speaks in an "old professor's language," by just adding an expression to the end of the sentence. For example, adding "...meow" or "...ja" to the end of sentences changes the sentence to "I am a cat, meow" or "I am an old professor ja." The Japanese native speakers can recognize the speaker and imagine what kind of a person (or an animal or an alien) the speaker is, through the first person pronouns or the expressions at the end of the sentence. Kinsui $(2003$, p. 205) calls this specific use of wordings that are closely related with the characteristics of the speakers and help listeners to imagine the speakers "role language". Sadanobu (2011, p. 116) further talks about "speaker's character" concerning those characters or people who talk using "role language". "Role language" can be found not only in Japanese anime and manga, but also in novels, TV drama series, and even in a Japanese daily conversation.

When teaching Japanese language in the Russian Novosibirsk, it is not rare that Japanese learners speak using "role language" from anime and manga, or they ask teachers about "role language" (Sadanobu et al., 2013, p. 281), however, "role language" is not taught in Japanese courses around Russia. For that reason, improper uses of "role language" by learners sometimes causes uncomfortable or unpleasant feelings for native Japanese speakers. For example, some Russian teachers of Japanese language (NNT) always write Maido arigatou gozaimasu. or "Thank you every time." at the end of an e-mail just like a shopkeeper. Some students sometimes say to me Ohairi. ("Come in.") without kudasai ("please."). It sounds like something a Queen would say. One of the students who uses Ohairi. said that she had heard the expression somewhere before and used it but had no intention to speak like a Queen. This can be regarded as an example that the speaker unintentionally spoke a "role language" which she learned through anime or manga. She was then looked at as a Queen, which is a different "speaker's character" then her own.

To reduce these kind of mistakes, Japanese language teachers in Novosibirsk, including the author, launched a research project about "role language" and the many different "speaker's characters". The members of this research project think that it is necessary to teach explicitly about "role language" and "speaker's characters" from the beginner stages of Japanese teaching in Russia.

In this paper, the author summarized the current situation of "role language" and the various "speaker's characters" in Japanese language teaching materials. Furthermore, the author introduced some of the results of the research project. 


\section{Current situation of "role language" and "speaker's character" in Japanese teaching materials}

It is not difficult to find Japanese teaching materials that were developed based on the importance of "role language" and the "speaker's character." An e-learning site by the Japan Foundation Kansai International Center called "Japanese Anime \& Manga" is a typical example of information about "role language" and the "speaker's character" in anime and manga. From this site, visitors can learn about "role language" such as basic greetings, grammar, alias, and pronunciation changes of the typical eight characters from anime and manga, "boy", "girl", "scrapper", "samurai", "old man", "lady", "butler", and "osakan" with voices by actors (Kumano \& Kawashima, 2011, pp. 112-113). The Japan Foundation (2013) reported that the annual amount of access to this page was about 3.13 million views and the amount of total access from 2009 was 10.97 million.

A Japanese textbook series "Character's Conversation" by Kai Japanese Language School is a good example of materials about more realistic "role language" and "speaker's characters" other than those from anime and manga. In this series, conversation of seven main characters, who were personified from five modes on the basis of transactional analysis, such as "controlling parent", "nurturing parent", "adult", "natural child", and "adapted child", is introduced. Transactional analysis is a kind of psychological theory, which has been applied as an effective tool for interpersonal communication training in educational institutions and companies (Matsuo \& Yamamoto, 2008). At Kai Japanese Language School, this series is used in elementary classes for learners studying Japanese for less than four months, with aims such as "being able to tell their own feelings well", "being able to speak feelings like they were their own", and "being able to produce what they want to show by adjusting their speech style to the scene or role (Matsuo et al., 2006). Matsuo et al. also cited some learners' comments such as "Thanks to this class, I know that various people speak by using various speech styles".

On the other hand, "role language", which is rarely used in natural conversation, has more often been published as a conversation example in textbooks on a higher level. Mizumoto et al. (2009) reported on their investigation of the actual use of female expressions used at the end of sentences such as ...wa and ...kashira by 36 native Japanese women in their 20 s to 40 s, and their use in five different Japanese textbooks. The results reveal that the realization rate of female sentence ending expressions was around 20\%, excluding the 39 and 47-year-old subjects. From the results of the textbook research, the following facts were revealed; (a) the realization rate for female sentence ending expressions in intermediate textbooks is higher compared to beginner textbooks, (b) in each of the five textbooks, realization rates for female sentence ending expressions are more than $60 \%$. In addition, in the conversation part of the listening comprehension of the Japanese Language Proficiency Test (JLPT) from 2003 to 2007, realization rates for female sentence ending expressions by female voice actors in their 20 s and 30 s were more than $40 \%$, 
and the rates in the old level 1 tests were slightly higher than in the old level 2 tests (Mizumoto et al., 2009).

\section{Research project in Novosibirsk}

The research project members in Novosibirsk investigated the use of first person pronouns and sentence ending expressions in six different textbooks to come to know about the current situation of "role language" in textbooks that are widely used for Japanese education in Russia. First person pronouns and sentence ending expressions are important indicators of the "role language" (Kinsui, 2003). The textbooks investigated were "Japanese for beginners <Японский язык для начинающих> (JFB)", "Let's read, write, and talk in Japanese <Читаем, пишем, говорим пояпонски> (RWT)", "Shokyu Nihongo 1, 2 (Shokyu)", "Minna no Nihongo 1,2 (Minna)", "J Bridge Intermediate (J Bridge)", and "Shadowing Let's speak Japanese intermediate to advanced level (Shadow)". Besides investigating the textbooks, the research members examined the awareness of Japanese language learners in Russia on the four most typical kinds of "role language" in Japanese anime and manga through a questionnaire and follow-up interviews.

\subsection{Textbook research}

From the results of the textbook research, authors clarified that (a) first person pronouns except for watashi are rarely used (details in Table 1), and (b) descriptions on boku are very general; they only state that boku is "male", "formal", and "used in conversation". Therefore, NNT cannot teach about first person pronouns except for watashi in classrooms. Furthermore, (c) some textbooks include explanations on the difference in gender by different sentence-ending expressions, however, they do not specify the speakers in details (example 1 and 2). For that reason, NNTs automatically teach about the difference of wordings by gender like "This speaker is a man, because he adds male particles such as ...dai?, ...kai?, and ...da. to the end of sentences.", or "This speaker is a woman, because she adds female particles to the end of sentences."

Table 1: First person pronouns in Japanese textbooks used in Novosibirsk

\begin{tabular}{|c|c|c|c|c|c|c||}
\hline \multicolumn{2}{|c|}{} & \multicolumn{5}{|c|}{ Textbooks } \\
\cline { 3 - 7 } \multicolumn{2}{|c|}{} & JFB & RWT & Shokyu & Minna & J Bridge \\
\hline \hline \multirow{3}{*}{$\begin{array}{c}\text { First } \\
\text { person } \\
\text { pronouns }\end{array}$} & Watashi & $\bigcirc$ & $\bigcirc$ & $\bigcirc$ & $\bigcirc$ & $\bigcirc$ \\
\cline { 2 - 7 } & Atashi & $\times$ & $\times$ & $\times$ & $\times$ & $\times$ \\
\cline { 2 - 7 } & Boku & $\bigcirc$ & $\bigcirc$ & $\times$ & $\bigcirc$ & $\bigcirc$ \\
\cline { 2 - 7 } & Ore & $\times$ & $\times$ & $\times$ & $\times$ & $\times$ \\
\hline \hline
\end{tabular}


Example (1) JFB: pp. 73-74

Read the following conversation and translate into Russian. Pay attention to the differences in conversation conducted by men (1) and women (2).

( $※$ Underlined by the author.)

\begin{tabular}{|c|c|c|}
\hline English translation & (1) Conversation by men & (2) Conversation by women \\
\hline $\begin{array}{l}\text { 1. How long does it take to } \\
\text { go to University? }\end{array}$ & $\begin{array}{l}\text { 1. Daigaku made donokurai } \\
\text { kakarundai? }\end{array}$ & $\begin{array}{l}\text { 1. Daigaku made donokurai } \\
\text { kakaruno? }\end{array}$ \\
\hline $\begin{array}{l}\text { 2. Well, I guess it takes } \\
\text { around an hour. }\end{array}$ & $\begin{array}{l}\text { 2. Sou dana. Ichi jikan gurai } \\
\text { kana. }\end{array}$ & $\begin{array}{l}\text { 2. Sou nee. Ichi jikan gurai } \\
\text { kashira. }\end{array}$ \\
\hline 3. I see. By bus? & 3. Sou. Basu de? & 3. Sou. Basu de? \\
\hline $\begin{array}{l}\text { 4. Yeah, by bus and subway. } \\
\text { I go to a subway station by } \\
\text { bus, then transfer to the } \\
\text { subway there. }\end{array}$ & $\begin{array}{l}\text { 4. Un, basu to chikatetsu. } \\
\text { Basu de chikatetsu no eki } \\
\text { made itte, sorekara } \\
\text { chikatetsu ni norikaerunda. }\end{array}$ & $\begin{array}{l}\text { 4. Ee, basu to chikatetsu. } \\
\text { Basu de chikatetsu no eki } \\
\text { made itte, sorekara } \\
\text { chikatetsu ni norikaeruno. }\end{array}$ \\
\hline $\begin{array}{l}\text { 5. Do a lot of buses run on } \\
\text { that route? }\end{array}$ & $\begin{array}{l}\text { 5. Basu no honsuu ha } \\
\text { ooinokai? }\end{array}$ & 5. Basu no honsuu ha ooino? \\
\hline $\begin{array}{l}\text { 6. No, not a lot. Sometimes I } \\
\text { have to wait for a long time. }\end{array}$ & $\begin{array}{l}\text { 6. Iya, amari ookunaine. } \\
\text { Tokidoki nagai jikan } \\
\text { matsuyo. }\end{array}$ & $\begin{array}{l}\text { 6. Uun, amarhi ookunaiwa. } \\
\text { Tokidoki nagai jikan } \\
\text { matsuno. }\end{array}$ \\
\hline (omitted) & (omitted) & (omitted) \\
\hline
\end{tabular}

Example (2) Shadow: p. 20 ( $※$ Underlined by the author.)

A (woman's voice): Taro no sugaku no tesuto wo mite. 28 ten to 32 ten dawa. (Look at Taro's scores on the math test. 28 points and 32.)

$B$ (man's voice): 50 ten manten? (50-point scale?)

A: 100 ten manten yo. Anata, hontouni rakkantekina hitone. (100-point scale. You are such an optimistic person.)

B: Maa, iijanaika. Kaeru no ko ha kaeru dayo. (Well, it's not a big problem. The apple never falls far from the tree.)

\subsection{Awareness survey}

Authors carried out an awareness questionnaire survey conducted on 210 Russian native speakers, who are learners of Japanese, including junior and senior high school students, university students, working people, and NNTs. The research was conducted in Novosibirsk, Yuzhno-Sakhalinsk, and Moscow in the period from April 1 to October 31, 2014. After that, authors interviewed five of the people surveyed in Novosibirsk. 
To compare the results, authors carried out the same awareness questionnaire survey with nine Japanese native speakers, five men and four women in their 20 s to $40 \mathrm{~s}$, who in that time were visiting Novosibirsk.

In the questionnaire, the participants answered questions on four characters defined by Kinsui (2003); "lady", "samurai", "fake Chinese", and "old professor" (Table 2 ). First, the participants answered questions about what kind of impression they had of the four characters. After that, they were ordered to combine the correct "role language" to each of the illustrations of the characters. The phrase was "Yes. That's me." and the authors presented three choices of this sentence for each character.

Table 2: Illustrations and "role languages" of the "speakers' characters"

\begin{tabular}{|c|c|c|c|}
\hline Lady & Samurai & Fake Chinese & Old professor \\
\hline & & & L \\
\hline $\begin{array}{l}\text { 1. Sou degozaimasu. Sore } \\
\text { ha watakushime } \\
\text { degozaimasu. }\end{array}$ & $\begin{array}{l}\text { (1) Sayou degozaru. Sore } \\
\text { ha sessha degozaru. }\end{array}$ & $\begin{array}{l}\text { 1. Sou nari. Sore, } \\
\text { watashi nari. }\end{array}$ & $\begin{array}{l}\text { 1. Sou sa. Sore ha boku } \\
\text { sa. }\end{array}$ \\
\hline $\begin{array}{l}\text { (2.)Sou desuwa. Sore ha } \\
\text { watakushi desuwa. }\end{array}$ & $\begin{array}{l}\text { 2. Seya. Sore ha washi } \\
\text { ya. }\end{array}$ & $\begin{array}{l}\text { 2. Sou sa. Sore, watashi } \\
\text { sa. }\end{array}$ & $\begin{array}{l}\text { (2.)Sou ja. Sore ha washi } \\
\text { ja. }\end{array}$ \\
\hline $\begin{array}{l}\text { 3. Sou dearimasu. Sore } \\
\text { ha jibun dearimasu. }\end{array}$ & $\begin{array}{l}\text { 3. Sou yo. Sore ha atashi } \\
\text { yo. }\end{array}$ & $\begin{array}{l}\text { (3.) Sou aruyo. Sore, } \\
\text { watashi aru. }\end{array}$ & $\begin{array}{l}\text { 3. Sou dayo. Sore ha ore } \\
\text { dayo. }\end{array}$ \\
\hline
\end{tabular}

From the results of the impression research and the matching test, authors could conclude the following three things; (a) some of the learners, who have had the same impression of the characters as Japanese native speakers, combined the wrong "role language" to the illustrations of the characters, (b) results of the matching between the "lady", "samurai", and "old professor" and their "role language" have low positive correlation with the learners' JLPT results, (c) matching results of all four kinds of characters to their "role language" have no correlation with other factors such as how long the student has been learning Japanese, how long have they been living in Japan, or the frequency of their use of Japanese outside the classroom, their watching Japanese anime/TV drama/movies, or whether or not they have been reading Japanese novels or manga. Additionally, students' comments from the follow-up interviews revealed that there is a possibility that some learners automatically determine that ...wa as an expression at the end of a sentence is only used by women, and that ...gozaru is a polite expression used at the end of a sentence. Detailed information is given in Shukuri et al. (2015). 


\section{Conclusion}

In this paper, the author summarized current situation concerning "role language" and "speaker's characters" used in Japanese teaching materials. As mentioned above, some materials have already developed the concepts of "role language" and "speaker's characters", and can be found on the Internet as well as in Japanese classrooms.

Also, the author introduced a research project where first person pronouns and expressions at the end of sentences were investigated in six different textbooks, and where researchers examined the awareness of Japanese language learners in Russia concerning four typical kinds of "role language" in Japanese anime and manga through a questionnaire and follow-up interviews.

Results of the textbook research, revealed two things; (a) first person pronouns except for watashi are rarely used, (b) boku lacks detailed descriptions, and is only explained as "male", "formal", and "used in conversation." It is difficult for NNTs to teach about first person pronouns in Russian classrooms, because there are no detailed explanations about different "speaker's characters".

The findings of the questionnaire show that some of the learners, who have the same impression of the characters as Japanese native speakers, combined the wrong "role languages" to the illustrations of the characters. The results of the three kinds of "role language" have low positive correlation with the learners' results of the Japanese Language Proficiency Test. On the other hand, the results of the four kinds of "Role language" respectively have no correlation with other factors, such as the students' duration of learning Japanese language, or the frequency of Japanese language use outside the classroom. In addition, there is a possibility that learners' misuse of the correct "role language" could lead Japanese speakers to misunderstand the situation., and that teaching materials are working in some ways since the stereotype that the expression "...wa" is used only by women" at the end of a sentence seems to have been understood by most students.

The members of this research project are going to incorporate these results of the textbook research and the awareness survey into the future Japanese curriculum with the aim that learners will not make native Japanese speakers uncomfortable or feel unpleasantly by their incorrect use of the "role language". As a concrete example, the members are planning a classroom activity in which a teacher presents a scene such as "When you talk with a native Japanese speaker you use one of the four kinds of "role language" from the awareness survey. However, the native Japanese listener looks upset." The learners' task is to think of the reason why the Japanese native was upset.

Finally, the author hopes that this study will not strengthen the stereotypes on learners, but will instead help learners to choose their own "role language" and use it in Japanese. 


\section{References}

Kinsui, S. (2003). Vacharu nihongo: Yakuwarigo no nazo [Virtual Japanese: Mystery of Role Language]. Tokyo: Iwanamishoten.

Japan Foundation Kansai International Center (2008). Anime-Manga no nihongo [Japanese in Anime and Manga]. Retrieved October 24, 2015, from http://animemanga.jp

Japan Foundation (2013). Japan Foundation 2013 nendo nenpoushiryou [Japan Foundation 2013 annual report] . Retrieved October 24, 2015, from https://www.jpf.go.jp/j/about/result/ar/2013/07_02.html

Kumano, N., \& Kawashima, K (2011). Anime-Manga no nihongo Web site kaihatsu: Shumi kara nihongo gakushuu he [Development of Web site Japanese in Anime and Manga: From a hobby to learning Japanese], Nihongo kyouiku kiyou [The Japan Foundation Japanese-Language Education Bulletin], 7, pp. 103-117.

Matsuo, E., Masuda, A., Matsumoto, N., Kuramoto, F. \& Kouno. T. (2006) Kyarakuta kaiwa [Characters' conversation]. Tokyo: Kai Japanese Language School.

Matsuo, E., \& Yamamoto, H., (2008). Higengo toreningu ni muketa aratana approach: "Kyarakuta kaiwa" kaihatsu wo tooshite [A new approach for non-verbal training; Through the development of "Characters' conversation"], Heisei 20 nendo Nihongo gakkou kyouiku kenkyuu taikai happyou shiryou [Japanese school education research convention presentation in 2008].

Mizumoto, M., Fukumori, S., \& Takada, K., (2009). Nihongo kyouzai ni miru josei Bunmatsushi: jisshakai ni okeru shiyou jittai chousa tono hikaku bunseki [Female sentence-final particles in Japanese teaching aids: Comparative analysis with the usage survey in the real world], Nihongo to gender [Japanese and Gender], 9. Retrieved October 24, 2015, from http://www.gender.jp/journal/no9/02_mizumoto.html

Sadanobu, T. (2011). Nihongo nozoki kyarakuri [Peeping the mechanisms of characters in Japanese]. Tokyo: Sanshoudou.

Sadanobu, T., Tomosada, K., Shu, S., Hayashi. R., Shukuri, Y., \& Shochi, T., (2013). Kyarakuta to denshi shiryo wo kushi sita nihongo kyouiku no shin tenkai [New Development of teaching Japanese with character and electronic resources], Yoropa nihongo kyouiku symposium houkoku happyou ronshu [Japanese language education in Europe], 17, Association of Japanese Language Teachers in Europe, pp. 277-282.

Shukuri, Y., Purik, I., Mironova, L., Novikova, O., Kalyuzhnova, M., Simonova, E., \& Ouchi, M., (2015). Roshiago bogowasha no nihongo yakuwarigo ni kansuru ishiki chousa: Anime-Manga no yakuwarigo ni chumoku shite [How do Russian native speakers recognize Japanese Role language in Anime and Manga?: Results of the awareness survey], Nihon gengo bunka kenkyukai ronshu [Journal of Japanese language and culture], 11, pp. 19-38. 